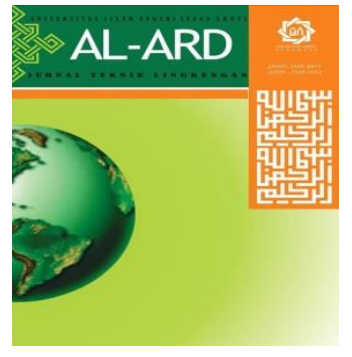

Al-Ard:

Al-Ard: Jurnal Teknik Lingkungan

Vol.6 No.1 - September 2020 (hal. 44-52)

http://jurnalsaintek.uinsby.ac.id/index.php/alard/index
Jurnal

Teknik Lingkungan

\title{
Fitoremediasi Tanaman Apu-Apu (Pistia Stratiotes) terhadap Kadar Logam Zn Berdasarkan Variasi Jumlah Tanaman Laili Oktaviani ${ }^{1}$, Widya Nilandita ${ }^{2}$, Dedy Suprayogi ${ }^{3}$ \\ 1,2,3 Universitas Islam Negeri Sunan Ampel Surabaya, Kota Surabaya, Indonesia $\underline{\text { lailioktaviani25@gmail.com }}^{1}$
}

\begin{abstract}
$\mathrm{Zn}$ is a heavy metal that is widely used to meet industrial needs. Increased use of Zn caused water pollution. To reduce waste products from industries that produce Zn can be done by phytoremediation techniques. In this research, the phytoremediation is carred out by utilizing Pistia stratiotes as phytoremediation plants. This research was conducted with the aim to determine the efficiency of absorption of heavy metal $\mathrm{Zn}$ by Pistia stratiotes by varying the number of plants varying the number of plants used. Namely 10 and 15 plants with a residence time of 10 days and with an initial concentration of 11,02 ppm. The result of this study indicate that the reactor $\mathrm{B}$ has a zink $(\mathrm{Zn})$ removal efficiency of $83,85 \%$ and the reacor $\mathrm{C}$ has a removal efficiency of $79,50 \%$.
\end{abstract}

Keyword: Zink heavy metal, Phytoremediation, Pistia stratiotes, Batch System

\begin{abstract}
Abstrak
Zn merupakan logam berat yang banyak digunakan untuk memenuhi kebutuhan industri. Meningkatnya penggunaan Zn menyebabkan pencemaran air. Untuk mereduksi hasil buangan dari industri yang menghasilkan Zn dapat dilakukan dengan cara teknik fitoremediasi. Pada penelitian ini, fitoremdiasi yamg dilakukan yaitu dengan memanfaatkan tanaman Apu-Apu (Pistia stratiotes) sebagai tanaman fitoremediator. Penelitian ini dilakukan dengan tujuan untuk mengetahui efisiensi penyerapan logam berat Zn oleh tanaman Apu-Apu dengan variasi jumlah tanaman yang berbeda. Variasi jumlah tanaman yang digunakan yaitu 10 dan 15 tanaman dengan waktu tinggal selama 10 hari dan dengan konsentrasi awal 11,02 ppm. Hasil penelitian ini menunjukkan bahwa pada reaktor B memiliki efisiensi removal logam berat Zn sebesar 83,85\% dan pada reaktor $\mathrm{C}$ memiliki efisiensi removal sebesar 79,50\%.

Kata Kunci: Logam Zn, Fitoremediasi, Pistia stratiotes, Sistem Batch
\end{abstract}

\section{PENDAHULUAN}

Pengembangan industri merupakan kebutuhan setiap negara untuk mendukung ekonominya karena dapat meningkatkan pertumbuhan ekonomi yang tinggi, menciptakan lapangan kerja serta dapat menyediakan kebutuhan dasar manusia. Perkembangan industri merupakan salah satu yang dapat menyebabkan peningkatan permasalahan lingkungan. Proses industrilisasi tidak dapat terlepas dari efek negatif yang dihasilkannya yaitu limbah. Limbah industri yang tidak diolah dengan baik akan mengakibatkan dampak negatif bagi lingkungan sekitar sehingga dapat menimbulkan pencemaran lingkungan. Air limbah yang berasal dari industri sangat bervariasi dari jenis industrinya. Industri tersebut selain memiliki kegunaan untuk menghasilkan suatu produk yang bermanfaat, dapat menghasilkan juga produk samping yang berupa limbah yang berbahaya dan beracun (B3). Limbah industri yang bersifat racun tersebut antara lain dapat berupa logam berat (Said, 2010). Kegiatan komersial seperti pengolahan logam, pertambangan, pembangkit energi panas, pabrik kertas, pembuatan pestisida, dan penyamakan kulit bertanggung jawab atas kontaminasi global logam berat yang dihasilkannya (Ali dkk., 2020). Logam berat dibagi menjadi dua jenis yaitu logam berat esensial dan logam berat non esensial. Logam berat esensial merupakan logam berat yang dibutuhkan oleh hewan, tumbuhan, maupun manusia. Logam berat esensial ini contohnya antara lain adalah; $\mathrm{Mn}$, $\mathrm{Cu}, \mathrm{Fe}, \mathrm{Co}, \mathrm{Zn}$, dan lain sebagainya. Keberadaan logam berat esensial jika dalam 
kadar yang sedikit tidak berbahaya untuk setiap organisme hidup, tetapi apabila dalam kadar yang banyak akan menyebabkan efek racun. Sedangkan logam berat non esensial merupakan logam berat yang keberadaanya didalam tubuh belum diketahui manfaatnya, bahkan dapat bersifat racun. Logam berat non esensial ini contohnya antara lain adalah; $\mathrm{Pb}, \mathrm{Cd}, \mathrm{Hg}, \mathrm{Cr}$, dan lain sebagainya (Darmono, 1995). Salah satu logam berat terdapat pada kandungan limbah industri tersebut adalah seng. Seng merupakan logam berat yang banyak digunakan dalam berbagai jenis industri diantaranya adalah; pabrik cat, pabrik obat-obatan, pabrik kosmetik, pabrik tinta, pabrik tekstil, dan lain sebagainya. Seng memiliki karakteristik cukup reaktif, berwarna putih kebiruan, pudar apabila terkena uap udara dan terbakar apabila terkena udara dengan api menyala hijau terang (Widowati dkk., 2008). Kegiatan pabrik secara terus menerus akan menghasilkan limbah cair dengan kadar logam Zn tinggi dan dapat mengakibatkan pencemaran lingkungan apabila limbahnya dibuang langsung ke lingkungan. Baku mutu limbah cair bagi kawasan industri untuk parameter logam Zn menurut Peraturan Gubernur Nomor 52 Tahun 2014 yaitu sebesar $10 \mathrm{mg} / \mathrm{l}$. Jika kadar Zn yang dihasilkan oleh industri melebihi baku mutu yang telah ditetapkan, maka akan berbahaya bagi lingkungan serta makhluk hidup.

Salah satu alternatif yang dapat dilakukan untuk mengurangi kadar logam $\mathrm{Zn}$ yang terdapat pada limbah industri yaitu dengan fitoremediasi. Fitoremediasi merupakan salah satu proses pemulihan lingkungan tercemar dengan memanfaatkan tanaman untuk mengurangi bahkan menghilangkan polutan yang terdapat pada limbah (Juhaeti, 2005). Fitoremediasi dapat didefinisikan sebagai penggunaan tanaman untuk memindahkan, menstabilkan atau menghancurkan polutan, baik senyawa organik maupun senyawa anorganik. Dengan kata lain, fitoremediasi dapat diterapkan untuk pengolahan limbah organik dan annorganik serta elemen logam berat yang antara lain: $\mathrm{As}, \mathrm{Cd}, \mathrm{Hg}, \mathrm{Pb}, \mathrm{Zn}, \mathrm{Ni}$, dan $\mathrm{Cu}$ dalam bentuk padat, cair, maupun dalam bentuk gas (M. Faizal dkk., 2018 dalam Salt et al., 1998). Keuntungan menggunakan fitoremediasi sebagai teknik pemulihan lingkungan yaitu ramah lingkungan, membutuhkan biaya yang sedikit, mudah diaplikasikan serta mengandung estetika.
Adapun kekurangan dalam teknik fitoremediasi yaitu membutuhkan waktu yang lama, bergantung pada iklim, sangat tergantung pada kedalaman akar dan toleransi tanaman terhadap kontaminan (Sidauruk \& Sipayung, 2015). Tanaman yang dapat digunakan untuk fitoremediasi adalah yang memiliki toleransi kontaminan yang tinggi.

Tanaman Apu-Apu (Pistia stratiotes) merupakan salah satu tanaman fitoremediator yang memiliki kemampuan untuk mengolah limbah, baik itu berupa logam berat, zat organik maupun anorganik. Pistia stratiotes merupakan salah satu spesies tanaman air dalam keluarga Aracae. Tanaman Apu-Apu tidak berbatang, berbentuk solet menyerupai mawar yang mana ujungnya membulat dan pangkalnya meruncing, daunnya bertulang jajar (Ramey, 2001 dalam Puspitasari \& Irawanto, 2016). Secara umum tanaman ApuApu adalah tanaman air yang biasa dapat dijumpai di kolam yang memiliki perairan yang tenang (Syafrudin dkk., 2015). Tanaman Apu-Apu berpotensi besar untuk menyerap logam berat seperti $\mathrm{Fe}, \mathrm{Zn}, \mathrm{Cu}, \mathrm{Cr}$, dan $\mathrm{Cd}$ tanpa menyebabkan toksisitas yang lain (Izzah dkk., 2017).

Penelitian Lestari Dwi Utami et al. (2017) menunjukkan kemampuan tanaman Apu-Apu dalam menurunkan logam berat Nikel (Ni). Adapun penurunan logam berat nikel ditunjukkan sebesar 2,516 $\mathrm{mg} / \mathrm{l}$ dengan perlakukan tanaman Apu-Apu sebanyak 2 tanaman; 2,188 $\mathrm{mg} / \mathrm{l}$ dengan perlakuan tanaman Apu-Apu sebanyak 3 tanaman; 1,566 mg/l dengan perlakuan tanaman Apu-Apu sebanyak 4 tanaman; dan 1,038 mg/l dengan perlakuan tanaman Apu-Apu sebanyak 5 tanaman untuk lama waktu kontak selama 6 hari.

Penelitian tentang penggunaan tanaman Apu-Apu dalam fitoremediasi sudah pernah dilakukan seperti penelitian yang dilakukan oleh Indah Sri Rahma et al., (2014) bahwa tanaman Apu-Apu mengalami pertambahan berat segar sebesar 33,65 gr pada limbah pabrik karet dengan konsentrasi 25\%. Hal ini dapat disimpulkan bahwa tanaman Apu-Apu mampu hidup pada limbah pabrik karet yang mengandung Zn.

Penelitian Pebri Nurhayati et al. (2012) menunjukkan tanaman Apu-Apu mampu menurunkan logam $\mathrm{Zn}$ dengan sistem regenerasi dan non regenerasi. Pada penelitiannya tanaman Apu-Apu (Pistia stratiotes) dengan sistem regenerasi mampu 
meremoval $\mathrm{Zn}$ hingga 2 ppm dengan konsentrasi awal sebesar 20 ppm, sedangkan dengan sistem regerenasi, tanaman Apu-Apu mampu meremoval $\mathrm{Zn}$ hingga 1,3 ppm dalam waktu empat hari.

Berdasarkan hal tersebut, penelitian ini bertujuan untuk mengetahui perubahan kadar logam Zn setelah perlakuan dengan tanaman Apu-Apu dengan variasi jumlah 10 dan 15 tanaman dalam waktu 10 hari. Penelitian ini menggunakan tanaman Apu-Apu, dikarenakan tanaman Apu-Apu memiliki keunggulan dibandingkan dengan tanaman lainnya seperti memiliki daya berkecambah yang tinggi, mampu menyerap unsur hara dan air yang besar, daya adaptasi yang tinggi terhadap ikim, dan pertumbuhannya cepat (Fahrurozie et.,al dalam Utami dkk., 2017). Klasifikasi tanaman Apu-Apu sebagai berikut

$\begin{array}{ll}\text { Kingdom } & \text { :Plantae } \\ \text { Subkingdom } & \text { :Tracheobionta } \\ \text { Superdivision } & \text { :Spermatophyta } \\ \text { Division } & \text { :Magnophyta } \\ \text { Class } & \text { :Liliopsida } \\ \text { Subclass } & \text { :Arecidae } \\ \text { Ordo } & : \text { Arales } \\ \text { Family } & : \text { Araceae } \\ \text { Genus } & : \text { Pistia L. } \\ \text { Spesies } & \text { :Pistia stratiotes L. }\end{array}$

Penelitian ini dilakukan dengan menggunakan sistem aliran batch. Dalam sistem batch, air yang difitoremediasi dalam keadaan diam dan tidak mengalir. Keuntungan menggunakan sistem batch yaitu mudah pengoperasiannya (Rosmiati dkk., 2014).

\section{METODE PENELITIAN}

Penelitian ini merupakan penelitian eksperimental skala laboratorium. Penelitian ini dilakukan pada bulan Februari hingga Juli 2020. Sampel penelitian ini berupa limbah artifisial logam $\mathrm{Zn}$ dengan konsentrasi awal sebesar 11,02 ppm. Pembuatan limbah artifisial $\mathrm{Zn}$ dilakukan di Laboratorium Universitas Islam Negeri Sunan Ampel Surabaya. Penelitian ini dilakukan di Greenhouse mandiri yang terbuat dari bahanbahan antara lain; kayu palet sebagai dudukan reaktor, jaring paranet sebagai penutup, plastik UV sebagai penutup atas greenhouse, kawat, dan pipa paralon berukuran kecil. Pengujian sampel limbah artifisial Zn dilakukan oleh Balai Riset dan Standarisasi Industri Surabaya (Baristand). Alat yang digunakan pada saat penelitian antara lain; reaktor batch, aerator, pipet tetes, gelas ukur, beaker glass, labu erlenmayer, suhu air raksa, thermometer air raksa, jerigen, $\mathrm{pH}$ meter, nerca analitik, spatula, botol coklat berukuran $50 \mathrm{ml}$, timbangan digital, dan alat tulis. Sedangakan bahan yang digunakan antara lain; larutan akuades, serbuk logam Zn $\left(\mathrm{ZnSO}_{4}\right)$, tanaman Apu-Apu (Pistia stratiotes), dan air bersih. Sebelum tanaman Apu-Apu digunakan untuk penelitian, tanaman Apu-Apu terlebih dahulu di aklimatisasi selama 7 (tujuh) hari dengan menggunakan air bersih berupa air PAM. Tujuan aklimatisasi ini yaitu agar tanaman Apu-Apu dapat beradaptasi dengan lingkungan baru (Istighfari dkk., 2018). Reaktor A merupakan kontrol yang hanya berisi larutan limbah artifisial, reaktor B berisi air limbah artifisial dengan jumlah tanaman Apu-Apu sebanyak 10 tanaman, dan reaktor C merupakan reaktor yang berisi limbah artifisial dengan jumlah tanaman sebanyak 15 tanaman. Limbah artifisial merupakan limbah buatan. Dalam penelitian ini, limbah artifisial ini dibuat dengan cara melarutkan serbuk $\mathrm{ZnSO}_{4}$ sebanyak 4,34 gr kedalam labu erlenmayer yang berisi akuades sebanyak $1000 \mathrm{ml}$. Setelah serbuk $\mathrm{ZnSO}_{4}$ telah ditambahkan kedalalam labu erlenmayer kemudian ditutup lalu dihomogenkan dengan cara menggoyang-goyang kan labu erlenmayer secara perlahan. Pengambilan sampel air limbah artifisial pada penelitian ini dilakukan setiap hari selama 10 hari pada setiap reaktor sebanyak $50 \mathrm{ml}$. Setelah sampel diambil, kemudian dibawa menuju Laboratorium Baristand Surabaya (Balai Riset dan Standarisasi) untuk di analisa kadar Zn nya. Pengamatan kondisi fisik lingkungan serta pengamatan kondisi fisik tanaman Apu-Apu dilakukan juga selama setiap hari selama 10 hari. Pengamatan kondisi lingkungan berupa suhu air pada setiap reaktor, $\mathrm{pH}$ air pada setiap reaktor, dan juga suhu ruangan pada saat penelitian. Hal ini dilakukan karena proses fitoremediasi dapat dipengaruhi oleh suhu lingkungan. Variabel independen yang digunakan pada penelitian ini yaitu jumlah tanaman Apu-Apu, sedangkan variabel dependen pada penelitian ini yaitu konsentrasi logam Zn. Data hasil pengukuran logam berat $\mathrm{Zn}$ diolah dengan menggunakan uji statistik One Way Anova. 


\section{HASIL DAN PEMBAHASAN}

1. Suhu dan $\mathrm{pH}$

Suhu air pada tahap aklimatisasi berkisar antara $28 \mathrm{C}-32 \mathrm{C}$ sedangkan suhu ruangan pada saat penelitian berkisar antara $28 \mathrm{C}-30^{\circ} \mathrm{C}$ dan $\mathrm{pH}$ pada saat aklimatisasi berkisar antara 6,0 6,6. Suhu air pada saat penelitian berkisar antara $27 \mathrm{C}-30 \mathrm{C}$ sedangkan suhu ruangan pada saat penelitian berkisar antara $28 \mathrm{C}-32 \mathrm{C}$, dan $\mathrm{pH}$ pada saat penelitan berkisar antara 5,5-6,7. Menurut Effendy (2013), meningkatnya pH dapat disebabkan karena proses fotosintesis tanaman yang digunakan pada saat penelitian. Pada saat fotosintesis tanaman berlangsung, $\mathrm{CO}_{2}$ akan diubah menjadi $\mathrm{C}_{6} \mathrm{H}_{12} \mathrm{O}_{6}$ yang memerlukan hidrogen dan energi. Hidrogen didapatkan dari $\mathrm{H}^{+}$yang diperoleh dari air limbah dan udara. Sedangkan penurunan $\mathrm{pH}$ pada saat penelitian, dapat disebabkan karena kerusakan pada tanaman yang diakibatkan karena nekrosis pada daun, bagian nekrosis yang masuk ke dalam media tumbuh akan terdekomposisi dan menghasilkan asam humat yang menyebabkan $\mathrm{pH}$ menurun (Azis dkk., 2014). Grafik nilai pH pada saat penelitian dapat dilihat pada gambar 1 . Menurut (Rahmatullah, 2008) suhu optimal pada bak berkisar antara $17 \mathrm{C}$ 35 C. Perubahan suhu baik naik maupun turun yang terjadi didalam reaktor perlakuan dapat dipengaruhi oleh cuaca dan intensitas penyinaran matahari yang tidak tetap (Budiyono dkk., 2018). Peningkatan suhu akan berpengaruh terhadap tingkat penyerapan karena suhu berkaitan dengan metabolisme dan fotosintesis tumbuhan. Grafik nilai suhu air dapat dilihat pada gambar 2 .

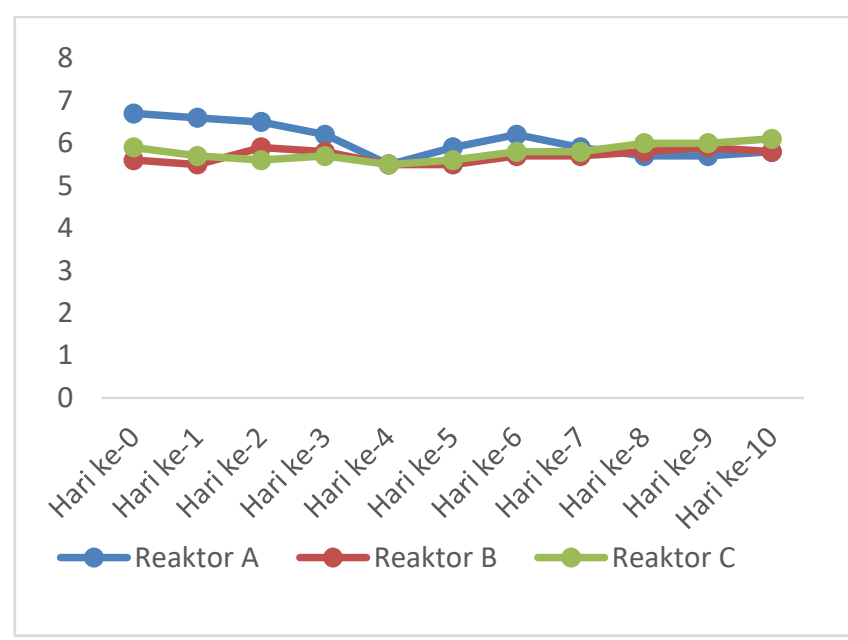

Gambar 1. Grafik Nilai pH

Sumber: Hasil Analisa,2020

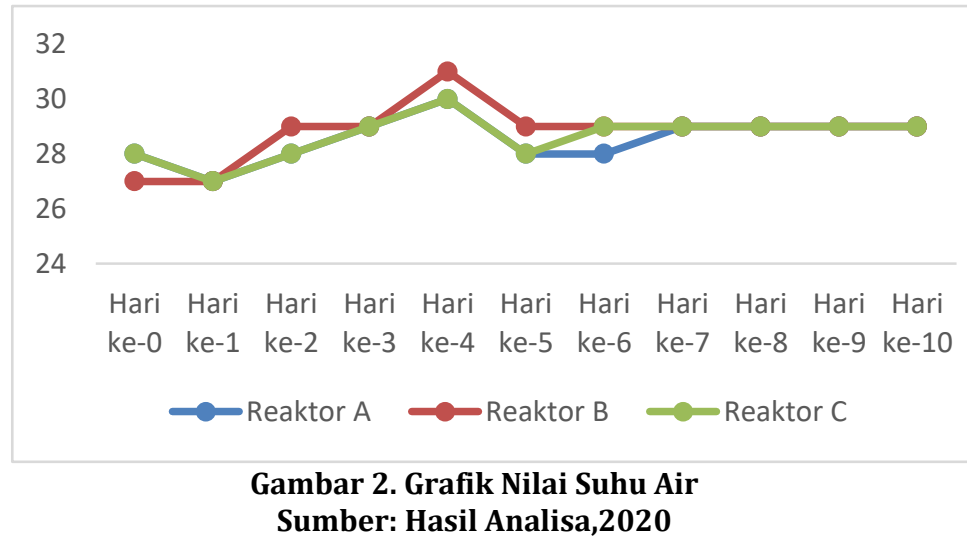

2. Penurunan nilai kadar Zn Setelah Fitoremediasi

Penurunan kadar Zn pada air limbah dengan lama waktu selama 10 hari pada reaktor $A$, reaktor $B$, dan juga reaktor $C$ dapat dilihat pada gambar 3 . dibawah ini

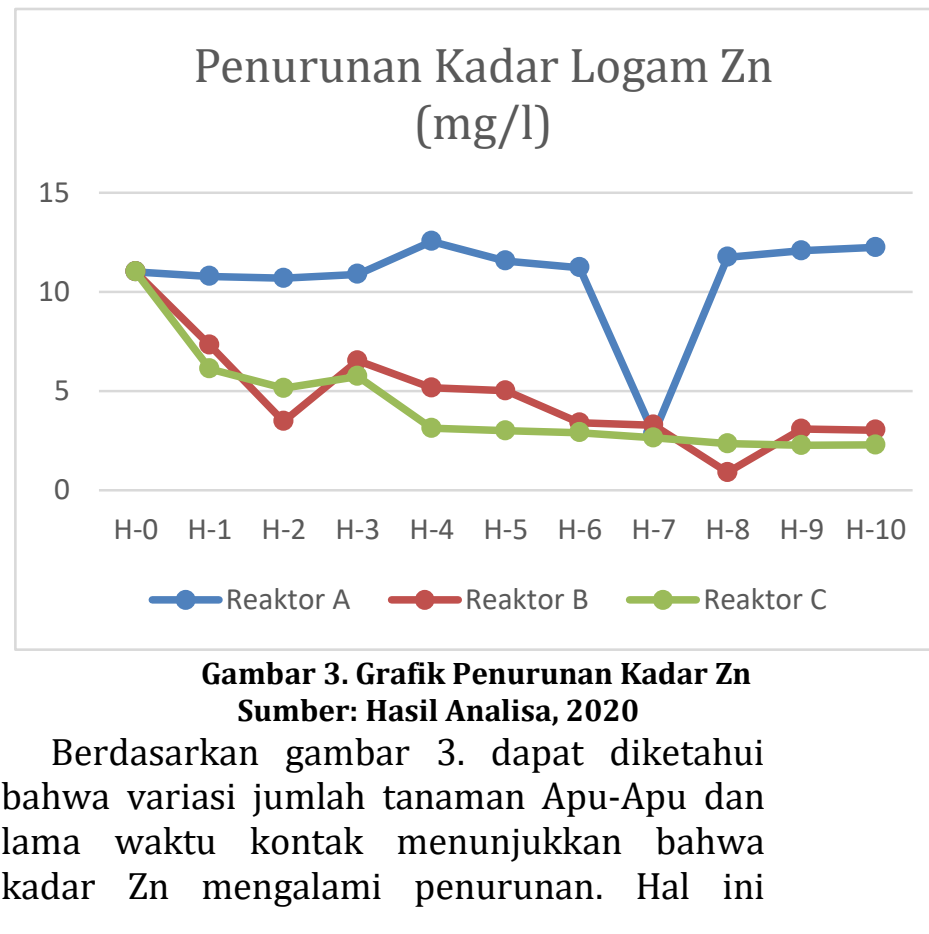


dikarenakan Tanaman Apu-Apu memiliki sifat yang hipertoleran, yakni mampu mengakumulasi logam dengan konsentrasi tinggi pada jaringan akar dan tajuknya, sehingga bersifat hiperakumulator (Hidayati, 2005). Tanaman Apu-Apu (Pistia stratiotes) merupakan salah satu makrofit air tawar paling produktif didunia yang memiliki sifat sangat toleran terhadap kontaminan air dan kandungan nutrisi yang tinggi dari air limbah industri atau air yang tercemar lainnya. (Shingadgaon \& Chavan, 2016).

Proses penyerapan polutan oleh tanaman Apu-Apu dengan perlakuan tanaman ApuApu-Apu berlangsung secara alami antara lain yaitu proses fitoekstraksi dan rhizofiltrasi (Utami dkk., 2017). Fitoekstraksi merupakan proses dimana tanaman menarik zat kontaminan oleh akar untuk menempel pada akar. Salah satu proses yang penting dalam fitoremediasi adalah rhizofiltrasi. Rhizofiltrasi merupakan proses dimana zat kontaminan diendapkan oleh akar dengan bantuan zat pengkhelat (Khiji and Bareen,. 2008 dalam Rosmiati dkk., 2014).

Pada hari ke-1, penurunan kadar Zn terjadi pada semua reaktor. Pada reaktor A, konsentrasi logam $\mathrm{Zn}$ turun hingga 10,78 $\mathrm{mg} / \mathrm{l}$. pada reaktor $\mathrm{B}$, konsentrasi logam $\mathrm{Zn}$ turun hingga $7,31 \mathrm{mg} / \mathrm{l}$, dan pada reaktor $\mathrm{C}$ konsentrasi logam Zn turun hingga 6,12 mg/l. hal ini dikarenakan kemampuan tanaman Apu-Apu pada awal percobaan dalam menyerap logam berat masih sangat tinggi. Penurunan kadar Zn disebabkan karena tanaman mampu menyerap dan mengakumulasikan logam berat kedalam jaringan akar dan daun.

Pada hari ke-2, penurunan kadar Zn pada reaktor B mengalami penurunan yang drastis yakni kadar Zn turun hingga 3,47 mg/l. Penurunan kadar logam Zn ini diduga karena kemampuan akar tanaman Apu-Apu yang masih kuat dan segar sehingga tanaman ApuApu memiliki kemampuan yang optimal dalam melakukan penyerapan terhadap logam $\mathrm{Zn}$. Sedangkan pada reaktor $\mathrm{C}$ juga mengalami penurunan kadar $\mathrm{Zn}$ tetapi tidak sebesar penurunan pada reaktor $\mathrm{B}$.

Pada hari ke-3, penurunan kadar Zn pada reaktor $\mathrm{B}$ mengalami kenaikan konsentrasi hingga $6,53 \mathrm{mg} / \mathrm{l}$. Hal ini dapat diduga bahwa tanaman Apu-Apu telah mengalami titik jenuh. Titik jenuh merupakan batas maksimum yang dapat ditolerir oleh tanaman dalam menyerap kontaminan. Setelah melewati titik jenuh, kemampuan tanaman dalam menyerap kontaminan menurun bahkan meningkat karena tanaman dapat melepaskan kembali kontaminan yang telah diserapnya. Sedangkan pada reaktor $\mathrm{C}$ juga mengalami kenaikan kadar Zn tetapi tidak menunjukkan hasil yang signifikan.

Pada hari ke-4, penurunan kadar Zn pada reaktor $\mathrm{B}$ mengalami penurunan yakni sebesar 5,16 mg/l. Penurunan kadar Zn meningkat pada reaktor $C$ yakni sebesar 3,12 $\mathrm{mg} / \mathrm{l}$. Dilihat dari hasil analisa dari hari ke-1 hingga ke-4, reaktor $\mathrm{C}$ mengalami penurunan kadar Zn yang stabil. Berbeda dengan penurunan kadar Zn yang terjadi pada reaktor B.

Pada hari ke-5, penurunan kadar Zn baik pada reaktor $\mathrm{B}$ maupun pada reaktor $\mathrm{C}$ tidak mengalami penurunan kadar $\mathrm{Zn}$ yang berbeda dari hari sebelumnya.

Pada hari ke-6, penurunan kadar Zn pada reaktor B mengalami penurunan sebesar 3,39 $\mathrm{mg} / \mathrm{l}$, lebih besar dari penurunan pada hari sebelumnya. Sedangkan pada reaktor C mengalami penurunan kadar Zn yang tidak begitu tinggi yakni sebesar 2,90 mg/l dari yang sebelumnya yakni 2,99 mg/l.

Pada hari ke-7 penurunan kadar Zn baik pada reaktor $\mathrm{B}$ maupun pada reaktor $\mathrm{C}$ tidak mengalami penurunan kadar $\mathrm{Zn}$ yang dapat dikatakan tinggi. Penurunan kadar Zn pada reaktor $\mathrm{B}$ dan reaktor $\mathrm{C}$ berbeda dari hari sebelumnya.

Pada hari ke-8, penurunan kadar logam Zn pada reaktor $\mathrm{B}$ mengalami penurunan yang tinggi yakni sebesar $0,89 \mathrm{mg} / \mathrm{l}$. Hal ini dapat disebabkan karena tanaman Apu-Apu mengalami titik jenuh. Pada saat titik jenuh, tanaman Apu-Apu melakukan proses penyerapan logam yang maksimum. Nilai kadar Zn hari ke-8 pada reaktor $\mathrm{C}$ yaitu sebesar 2,34 mg/l.

Pada hari ke-9, konsentrasi Zn pada reaktor B mengalami kenaikan yang sangat signifikan yakni sebesar $3.08 \mathrm{mg} / \mathrm{l}$. Hal ini dapat disebabkan karena tanaman Apu-Apu telah melewati titik jenuh. Pada saat tanaman telah melewati titik jenuh, dapat mengakibatkan kadar Zn meningkat karena tanaman melepaskan kadar logam Zn yang telah diserapnya pada hari sebelumnya. Pada reaktor $\mathrm{C}$, kadar $\mathrm{Zn}$ tidak mengalami penurunan yang signifikan yakni pada nilai 2,26 mg/l.

Pada hari ke-10, yakni pada hari terakhir penelitian, konsentrasi $\mathrm{Zn}$ pada reaktor $\mathrm{B}$ 
tidak mengalami penurunan yang tinggi yakni sebesar 3,02 mg/l. Sama hal nya dengan yang terjadi pada reaktor $\mathrm{C}$, nilai $\mathrm{Zn}$ pada hari ke-10 sebesar 2,28 mg/l. Berdasarkan hasil yang diperoleh, dapat diketahui bahwa yang paling tinggi mengalami penurunan kadar $\mathrm{Zn}$ yaitu pada reaktor $\mathrm{B}$ yakni perlakuan dengan jumlah tanaman sebanyak 10 tanaman pada hari ke-8.

Secara biologi, proses penyerapan unsurunsur kimia oleh tanaman air dilakukan melalui membran sel. Kation dari unsur-unsur kimia tersebut ada didalam molekul air dan dikelilingi oleh molekul air lainnya. Semakin banyak molekul air yang diserap oleh tanaman, maka semakin banyak juga ion-ion logam yang masuk ke dalam badan tanaman air (Syahputra, 2005 dalam Utami dkk., 2017).

Pengaruh variasi jumlah tanaman dalam penyerapan logam berat Zn pada penelitian ini dapat dilihat dari besarnya persentase penyerapan dari setiap perlakuan. Efisiensi removal kadar Zn dapat dilihat pada Tabel 1. dibawah ini.

Tabel 1. Efisiensi Penyerapan Kadar Zn

\begin{tabular}{ccc}
\hline \multirow{2}{*}{$\begin{array}{c}\text { Waktu Tinggal } \\
\text { (Hari) }\end{array}$} & \multicolumn{2}{c}{$\begin{array}{c}\text { Persentase Penyerapan } \\
\text { (\%) }\end{array}$} \\
\cline { 2 - 3 } & Reaktor B & Reaktor C \\
\hline Hari ke-1 & 33,66 & 44,46 \\
\hline Hari ke-2 & 68,51 & 53,35 \\
\hline Hari ke-3 & 40,74 & 47,91 \\
\hline Hari ke-4 & 53,18 & 71,69 \\
\hline Hari ke-5 & 54,54 & 72,87 \\
\hline Hari ke-6 & 69,24 & 73,68 \\
\hline Hari ke-7 & 70,24 & 76,13 \\
\hline Hari ke-8 & 83,85 & 78,76 \\
\hline Hari ke-9 & 72,05 & 79,50 \\
\hline Hari ke-10 & 72,60 & 79,31 \\
\hline
\end{tabular}

Sumber: Hasil Analisa, 2020

Berdasarkan Tabel 1. diatas, dapat diketahui bahwa tingkat persentase penyerapan logam $\mathrm{Zn}$ tertinggi pada reaktor B adalah sebesar $83,85 \%$ yakni pada hari ke-8 dan persentase penyerapan tertinggi pada reaktor C adalah sebesar $79,50 \%$ yakni pada hari ke-9. Seng mudah diserap dalam makrofit termasuk oleh tanaman Apu-Apu karena merupakan salah satu dari 17 zat gizi esensial yang dibutuhkan oleh tanaman Apu-Apu untuk pertumbuhannya yang sehat (Shingadgaon \& Chavan, 2016). Untuk mengetahui adanya perbedaan penurunan kadar Zn dengan variasi jumlah tanaman ApuApu pada penelitian ini, dilakukan analisa statistik menggunakan One Way Anova.
Sebelum dilakukannya uji One Way Anova, terdapat uji prasyarat yang harus dipenuhi yakni Uji Normalitas dan Uji Homogenitas. Berikut hasil uji prayarat yang telah dilakukan dapat dilihat pada tabel 2. dan pada tabel 3 .

Tabel.2 Uji Normalitas Kolmogorov-Smirnov

\begin{tabular}{|llr|}
\hline & & \multicolumn{2}{c|}{$\begin{array}{c}\text { Zn } \\
\end{array}$} \\
& & 33 \\
\hline Normal Parameters & Mean & 6.5833 \\
\cline { 2 - 3 } & Std.Deviation & 3.99809 \\
\hline Most Extreme & Abosolute & .211 \\
\cline { 2 - 3 } Differences & Positive & .206 \\
\cline { 2 - 3 } & Negative & -.211 \\
\hline Kolmogorov-Smirnov Z & & 1.215 \\
& & \\
\hline Asymp.Sig.(2- Tailed) & & .105 \\
\hline
\end{tabular}

Berdasarkan tabel 2. diatas, dapat dilihat bahwa uji normalitas menggunakan Kolmogorov-Smirnov mendapatkan nilai signifikasi Asymp.Sig. (2-tailed) sebesar $0,105>0,05$ yang mana dapat diartikan bahwa data berdistribusi normal. Setelah diketahui bahwa data berdistribusi normal, maka dilanjutkan dengan uji prasyarat yakni uji homogenitas yang dapat dilihat pada tabel 3 . dibawah ini.

Tabel 3. Uji Homogenitas Shapiro-Wilk

\begin{tabular}{|cccc|}
\hline $\begin{array}{c}\text { Levene } \\
\text { Statistic }\end{array}$ & df1 & df2 & Sig \\
\hline .392 & 2 & 30 & .679 \\
\hline
\end{tabular}

Sumber: Hasil Analisa, 2020

Berdasarkan tabel 3. diatas, uji prasyarat homogenitas memiliki nilai signifikasi sebesar $0,679>0,05$. Hal ini dapat dikatakan bahwa data yang didapatkan yaitu sama atau homogen. Dengan hal ini maka dapat dilanjutkan dengan uji One Way Anova. Hasil uji One Way Anova dapat dilihat pada tabel 4. dibawah ini.

Tabel 4. Hasil Uji One Way Anova

\begin{tabular}{|rccccc|}
\hline & $\begin{array}{c}\text { Sum of } \\
\text { Squares }\end{array}$ & df & $\begin{array}{c}\text { Mean } \\
\text { Square }\end{array}$ & F & Sig. \\
\hline $\begin{array}{r}\text { Between } \\
\text { Groups }\end{array}$ & 283.991 & 2 & 141.995 & 19.497 & .000 \\
\hline $\begin{array}{r}\text { Within } \\
\text { Groups }\end{array}$ & 218.484 & 30 & 7.283 & & \\
\hline Total & 502.475 & 32 & & & \\
\hline
\end{tabular}

Sumber: Hasil Analisa, 2020 
Berdasarkan tabel 4. diatas, analisa data menggunakan One Way Anova menghasilkan nilai signifikasi lebih kecil dari 0,05; sehingga secara statistik dapat diartikan bahwa terdapat perbedaan penurunan kadar Zn pada perlakuan 10 tanaman Apu-Apu dan 15 tanaman Apu-Apu. Hal ini terbukti bahwa pada reaktor B mampu menurunkan kadar Zn hingga $0,89 \mathrm{mg} / \mathrm{l}$ pada hari ke-8, sedangkan pada reaktor $\mathrm{C}$ kadar $\mathrm{Zn}$ turun hingga 2,34 ppm.

Persentase penyerapan kadar Zn yang semakin tinggi, dapat menyebabkan toksisitas pada tanaman semakin meningkat. Penyerapan yang dilakukan oleh tanaman Apu-Apu dapat memberikan pengaruh terhadap kondisi fisik tanaman Apu-Apu. Kondisi tanaman Apu-Apu pada saat aklimatisasi dapat dilihat pada gambar 4 . dibawah ini.

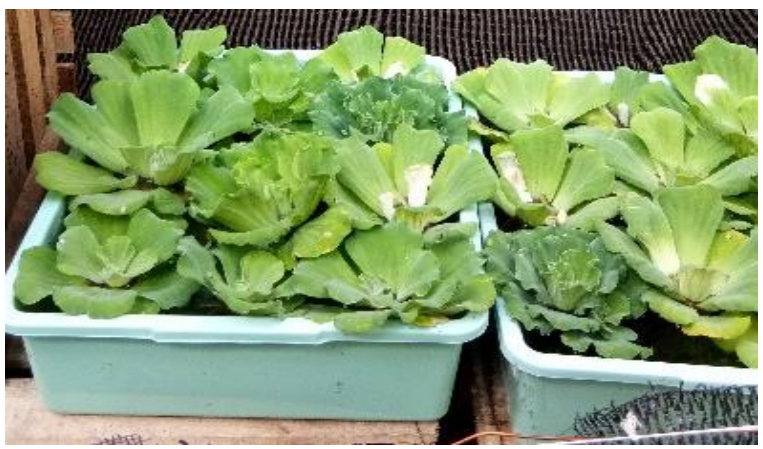

Gambar 4. Kondisi tanaman Apu-Apu pada saat Aklimatisasi

Sumber: Dokumentasi Pribadi, 2020

Tahap aklimatisasi dilakukan selama tujuh hari dengan cara menanam tanaman Apu-Apu didalam wadah bak plastik berukuran panjang $48 \mathrm{~cm}$ lebar $35 \mathrm{~cm}$ dan tinggi $15 \mathrm{~cm}$ yang berisi air bersih yakni air PAM. Pada tahap aklimatisasi, kondisi tanaman Apu-Apu terlihat segar dan memiliki daun yang sehat berwarna hijau terang.

Setelah proses aklimatisasi selesai, maka dilakukan proses fitoremediasi tanaman ApuApu terhadap logam $\mathrm{Zn}$ (seng) dalam waktu 10 hari. Kondisi fisik tanaman Apu-Apu pada awal dan akhir penelitian terdapat perbedaan. Perbedaan kondisi fisik tanaman Apu-Apu pada reaktor $\mathrm{B}$ dan reaktor $\mathrm{C}$ pada saat penelitian dapat dilihat pada tabel 5 .
Tabel 5. Perubahan Kondisi Fisik Tanaman Apu-Apu selama Proses Fitoremediasi

\begin{tabular}{|c|c|c|}
\hline $\begin{array}{l}\text { Waktu } \\
\text { tinggal } \\
\text { (hari) }\end{array}$ & Reaktor B & Reaktor C \\
\hline Hari ke-0 & & \\
\hline Hari ke-1 & & \\
\hline
\end{tabular}
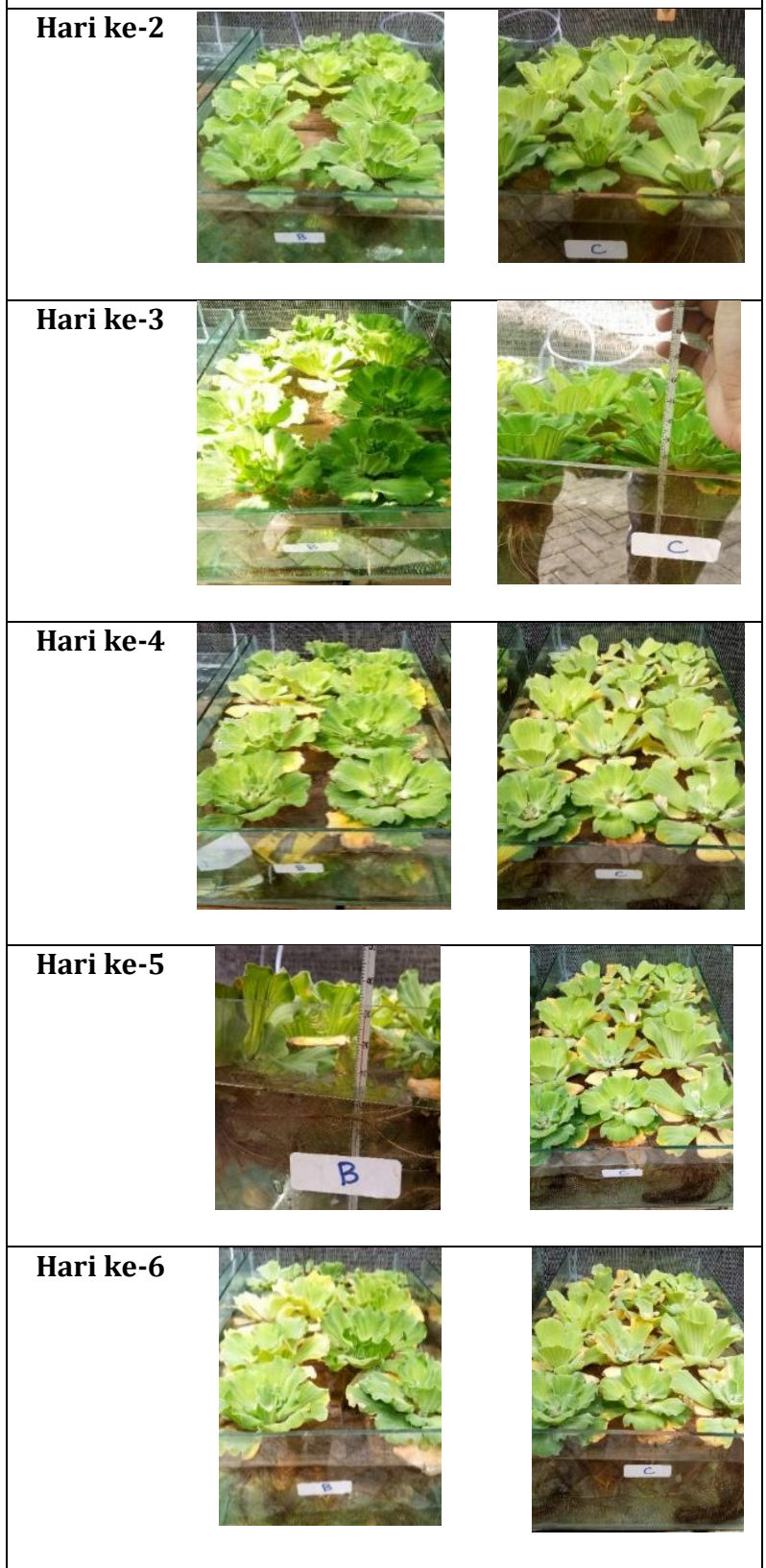


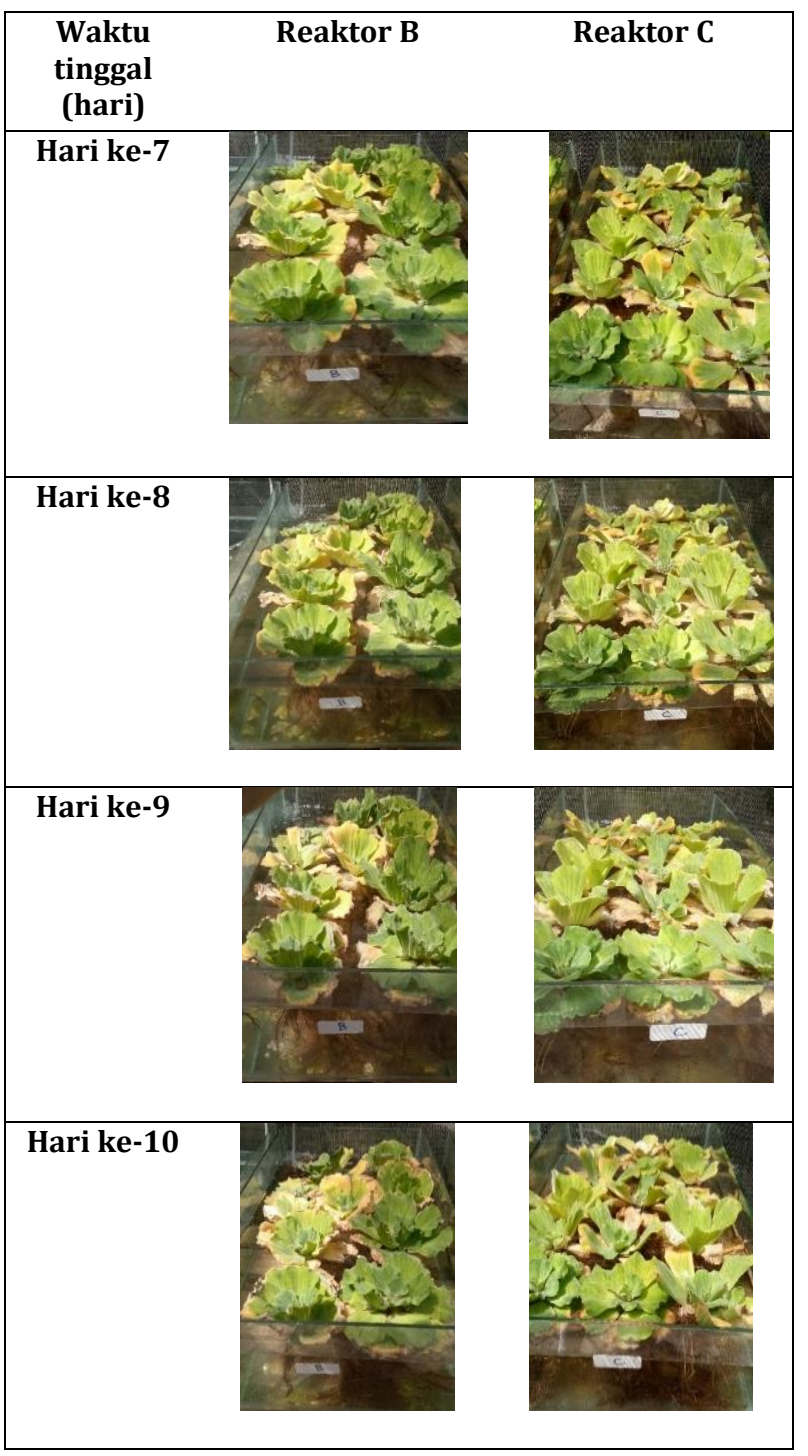

Sumber: Dokumentasi Pribadi,2020

Dapat dilihat pada tabel 5. bahwa perubahan fisik tanaman Apu-Apu dapat ditandai dengan perubahan warna daun yang semula berwarna hijau segar, berubah warna menjadi kuning dan kering. Pada hari ke-1 hingga hari ke-3 kondisi fisik tanaman ApuApu baik pada reaktor B maupun $\mathrm{C}$ masih terlihat daun berwarna hijau dan tumbuh sehat. Perubahan kondisi fisik tanaman ApuApu pada hari ke-4 ditandai dengan tanaman Apu-Apu mengalami perubahan warna daun pada ujung daunnya yakni berwarna kuning. Pada hari ke-5, tanaman Apu-Apu mengalami kerusakan pada daun, beberapa daun terlihat kering. Pada hari ke-6, tanaman Apu-Apu mengalami kerusakan pada daun dan juga akar, didasar reaktor terlihat akar yang rontok. Pada hari ke-7 kondisi tanaman ApuApu tidak berbeda jauh dari hari sebelumnya. Pada hari ke-8, warna daun tanaman Apu-Apu pada kedua reaktor dominan berwarna kuning dan daunnya terlepas dari badan tanamannya.
Pada hari ke-9 dan pada hari ke-10 terlihat kondisi fisik tanaman Apu-Apu semakin mengalami kerusakan baik pada daun dan juga akar. Hal ini dapat terjadi karena logam berat yang diberikan pada tanaman dalam jumlah tertentu dapat membantu mempercepat pertumbuhan tanaman bahkan dapat membuat tanaman mati sebagai respon negatif tanaman (Mangkoediharjo dan Samudro., 2010 dalam Utami dkk., 2017). Salah satu upaya yang dapat dilakukan oleh tumbuhan dalam menyerap bahan toksik dari lingkungan yaitu dengan cara lokalisasi yang biasanya terjadi pada akar tumbuhan (Ashraf et al, 2010 dalam Munawwaroh \& Pangestuti, 2018).

Hal ini dapat disebut sebagai klorosis. Klorosis dapat disebabkan karena logam berat menghambat kerja enzim yang mengkatalis sintesis klorofil (Nurlina dkk., 2016). Perubahan fisik tersebut dapat disebabkan karena konsentrasi logam Zn yang terlalu tinggi dapat menyebabkan kerusakan jaringan dalam sel daun. Hal ini biasa disebut dengan nekrosis.

Perubahan morfologi dan fisiologi tanaman yang digunakan sebagai fitoremediator dapat disebebkan karena tanaman tersebut telah aktif menyerap logam berat yang ada dilingkungan. Tanaman tersebut juga berusaha untuk beradaptasi agar dapat tetap hidup, namun fitoremediasi memiliki kelemahan yaitu sebaiknya diterapkan pada tingkat konsentrasi pencemar yang rendah. Adaptasi tumbuhan secara morfologi dapat dilihat dari warna daun, ukuran daun, serta akar tanaman, sedangkan adaptasi secara fisiologi dapat dilihat dari kemampuan genetis tanaman untuk toleran atau tidak toleran terhadap unsur-unsur kimia. Apabila tanaman fitoremediator diterapkan pada limbah dengan konsentrasi polutan yang tinggi, maka tanaman tidak dapat bertahan hidup dalam waktu yang lama dan efektivitasnya dalam menyerap limbah juga rendah (Munawwaroh \& Pangestuti, 2018).

\section{KESIMPULAN}

Berdasarkan hasil penelitian yang diperoleh, dapat disimpulkan bahwa penyerapan logam berat $\mathrm{Zn}$ oleh Tanaman Apu-Apu (Pistia stratiotes) selama 10 hari pada reaktor $\mathrm{B}$ dan reaktor $\mathrm{C}$ dengan variasi jumlah tanaman mengalami penurunan konsentrasi. Penurunan konsentrasi logam berat $\mathrm{Zn}$ pada reaktor B turun hingga 0,89 
ppm dan konsentrasi logam berat Zn pada reaktor $\mathrm{C}$ turun hingga 2,26 ppm. Pada penelitian ini diketahui bahwa reaktor $\mathrm{B}$ memiliki efisiensi removal logam berat $\mathrm{Zn}$ $83,85 \%$ dan pada reaktor $C$ memiliki efisiensi removal logam berat Zn sebesar 79,50\%. Hasil analisis data menunjukkan bahwa terdapat perbedaan penurunan logam berat $\mathrm{Zn}$ dengan variasi jumlah tanaman sebanyak 10 dan 15 tanaman dengan waktu tinggal selama 10 hari.

\section{DAFTAR PUSTAKA}

Ali, S., Abbas, Z., Rizwan, M., Zaheer, I. E., Yavaş, İ., Ünay, A., Abdel-Daim, M. M., Bin-Jumah, M., Hasanuzzaman, M., \& Kalderis, D. (2020). Application of Floating Aquatic Plants In Phytoremediation of Heavy Metals Polluted Water: A Review. Sustainability, 12(5), 1927. Https://Doi.Org/10.3390/Su1205192 7

Azis, Sri Rahma, I., \& Yelmida. (2014). Fitoremediasi Zn Dari Limbah Cair Pabrik Pengolahan Karet Dengan Pemanfaatan Pistia Stratiotes L. 1.

Budiyono, Wahyuningsih, N. E., \& Rahayuningtyas, I. (2018). Pengaruh Variasi Lama Waktu Kontak Dan Berat Tanaman Apu-Apu (Pistia Stratiotes L.) Terhadap Kadar Timbal Pada Irigasi Pertanian. 6.

Darmono. (1995). Logam Dalam Sistem Biologi Makhluk Hidup. Ui-Press.

Hidayati, N. (2005). Fitoremediasi Dan Potensi Tumbuhan Hiperakumulator. Hayati Journal of Biosciences, 12(1), 35-40. Https://Doi.Org/10.1016/S19783019(16)30321-7

Izzah, I., Supriatno, \& Wardiah. (2017). Kiambang (Pistia Stratiotes) Sebagai Agen Fitoremediasi Logam Krom (Cr).

Juhaeti, T. (2005). Inventarization Of Potential Plant For Phytoremediation On Degraded Land And Water Mined. Biodiversitas, Journal of Biological Diversity, 6(1), 31-33. Https://Doi.Org/10.13057/Biodiv/D0 60106

Munawwaroh, A., \& Pangestuti, A. A. (2018). Analisis Morfologi Dan Anatomi Akar Kayu Apu (Pistia Stratiotes L.) Akibat Pemberian Berbagai Konsentrasi Kadmium (Cd). 7(2), 12.
Nurlina, Suhadiyah, S., \& Umar, M. R. (2016, Agustus). Akumulasi Logam Berat Besi (Fe) Pada Kiapu Pistia Stratiotes L. Dari Air Sumur Sekitar Workshop Unhas. Prosiding Seminar Nasioanal From Basic Science To Comprehensive Education.

Puspitasari, D., \& Irawanto, R. (2016). Fitoremediasi Limbah Domestik Dengan Tumbuhan Akuatik Mengapung Di Kebun Raya Purwodadi. 11.

Rahmatullah, L. (2008). Penggunaan Tanaman Kiapu (Pistia Stratiotes) Sebagai Pengolahan Pendahuluan Untuk Air Permukaan Dengan Parameter Warna Dan TDS "Studi Kasus Air Selokan Mataram."

Rosmiati, Arsyad, A., \& Zubair, A. (2014). Fitoremediasi Logam Berat Kadmium (Cd) Menggunakan Kombinasi Eceng Gondok (Eichornia Crassipes) Dan Kayu Apu (Pistia Stratiotes) Dengan Aliran Batch.

Said, N. I. (2010). Metoda Penghilangan Logam Berat (As, Cd, Cr, $\mathrm{Ag}, \mathrm{Cu}, \mathrm{Pb}, \mathrm{Ni} \mathrm{Dan} \mathrm{Zn}$ ) Di Dalam Air Limbah Industri. 6(2), 13.

Shingadgaon, S. S., \& Chavan, B. L. (2016). Zinc Uptake Potential In Water Lettuce (Pistia Stratiotes, Linn). 7(4), 8.

Sidauruk, L., \& Sipayung, P. (2015). Fitoremediasi Lahan Tercemar Di Kawasan Industri Dengan Tanaman Hias. Vol.2, No. 2, 178-186.

Syafrudin, Zaman, B., \& Widya, C. (2015). Pengaruh Waktu Tinggal Dan Jumlah Kayu Apu (Pistia Stratiotes L.) Terhadap Penurunan Konsentrasi BOD, COD Dan Warna.

Utami, L. D., . N., \& Rahayu, U. (2017). Kemampuan Tanaman Apu- Apu (Pistia Stratiotes L.) Dalam Menurunkan Kadar Logam Berat Nikel (Ni) Limbah Cair. Gema Lingkungan Kesehatan, 15(1). Https://Doi.Org/10.36568/Kesling.V1 $5 i 1.576$

Widowati, W., Sastiono, A., \& Jusuf R, R. (2008). Efek Toksik Logam. Andi. 